\title{
PENINGKATAN KOMPETENSI GURU MADRASAH DALAM BIDANG PENULISAN KARYA TULIS ILMIAH UNTUK MENDUKUNG GERAKAN AYO MEMBANGUN MADRASAH (GERAMM)
}

\author{
Akhmad Sruji Bahtiar'), Abdul Wafi ${ }^{2)}$ \\ ${ }^{12)}$ Bidang Pendidikan Madrasah Kementrian Agama \\ ${ }^{1)}$ bahtiarsruji@gmail.com \\ ${ }^{2)}$ wafiabuahdan@gmail.com
}

\begin{abstract}
The movement let's build a madrasa (GERAMM) is a madrasa innovation program to improve quality towards a great and dignified madrasa. Among the GERAMM programs, one of them is the Madrasah Literacy Movement (GELEM) program with the aim of generating literacy activities in madrasas with the main target of teachers, principals, supervisors and students. The problem in this service is how to improve the quality of teachers in the field of writing scientific papers especially writing (a) research proposals, (b) reports of research results, and (c) scientific publications. The method used in this service is a workshop in which it is conducted with lectures, discussions and questions and answers. The results of the workshop were able to improve the ability of teachers in the field of scientific papers by $31 \%$ from the initial value before the workshop. The contribution of this service is to realize literacy programs in madrasas by equipping teachers with scientific writing skills, the GERAMM program is able to boost madrasa innovation towards superior madrasas.
\end{abstract}

Keywords: Geramm, Gelem, KTI

\section{PENDAHULUAN}

Kantor Wilayah Kementerian Agama Provinsi Jawa Timur telah meluncurkan Gerakan Ayo Membangun Madrasah (GERAMM) sebagai program untuk membangun madrasah dengan mengoptimalkan potensi madrasah. Melalui program ini diharapkan madrasah lebih berbenah mengoptimalkan diri berinovasi dalam mewujudkan madrasah hebat bermartabat (https://jatim.kemenag.go.id/ 2019)

GERAMM dibagi dalam 7 gerakan, yaitu Gerakan Literasi Madrasah (GELEM), Gerakan Madrasah Sehat (GEMES), Gerakan Madrasah Inovatif (GEMI), Gerakan Furudhul Ainiyah (GEFA), Gerakan Peningkatan Kompetensi Guru (KATA SIGURU), Gerakan Peningkatan Kompetensi Kepala Madrasah (KATA SIKAMAD), Gerakan Peningkatan Kompetensi Pengawas (KATA SIAWAS) (Dr. Achmad Syuruji 2019)

Program penguatan madrasah bertajuk Gerakan Literasi Madrasah (GELEM) yang diprogramkan oleh Kanwil Kementrian Agama Provinsi Jawa Timur tidak lepas dari tujuan mulia. Gelem diharapkan mampu menjadi sebuah gerakan yang dapat membangkitkan budaya literasi madrasah di Jawa Timur. Secara umum, budaya literasi sebenarnya sudah berurat akar dan menjadi bagian dari sendi kehidupan madrasah. Kegiatan baca, tulis dalam skala tertentu merupakan irama kehidupan madrasah, terutama literasi agama (Florentina Maria Titin Supriyanti 2009), (Ardinata 2016).

Kegiatan literasi meliputi 3 kegiatan, yaitu: kegiatan pembiasaan, kegiatan pengembangan dan kegiatan pembelajaran. (1) Kegiatan pembiasaan meliputi: penumbuhan minat baca melalui: (a) kegiatan 15 menit membaca setiap hari antara lain, yaitu: 5 menit membaca Al-quran, satu hari satu hadits, lingkar pagi, jurnal pagi, baca literature islam, (b) menata lingkungan karya tulis meliputi kegiatan mengubah kelas menjadi lingkungan kaya teks, pengadaan buku-buku nonpelajaran, perpustakaan yang nyaman, sudut baca dan gerobak baca, kafe

AKhmad Sruji Bahtiar - Peningkatan Kompetensi guru madrasah bidang penulisan Karya tulis ilmiah melalui gerakan ayo membangun madrasah (GERAMM) 
baca, gubuk literasi, majalah dinding dan poster-poster kampanye membaca menulis. (2) Kegiatan pengembangan meliputi: (a) menulis komentar pada jurnal, (b) mengungkapkan kembali, (c) mengungkapkan kosakata 4 bahasa, (d) frayer model, (e) penghargaan terhadap literasi, (f). Pengembangan literasi digital dan teknologi menggunakan internet, (g) melibatkan peserta didik dalam pengelolaan perpustakaan, (h) mengumpulkan karya guru-guru dan tenaga pendidik. (3) Kegiatan pembelajaran meliputi: (a) integrasi literasi dalam perencanaan pembelajaran, (b) integrasi literasi dalam proses pembelajaran, (c) integrasi literasi dengan nilai pembelajaran (Sedayu and Juli 2011), (Septiani 2019), (Septiani 2019).

Salah satu model gerakan literasi adalah melalui Madrasah Menulis (MANIS), meliputi: (1) Guru Menulis (Gelis) tujuanya adalah membudayakan guru menulis antara lain: (a) menulis buku ajar, (b) menulis esay praktek pembelajaran, (c) menulis laporan ilmiah, (d) menulis laporan hasil penelitian, (e ) menulis buku popular, (f) artikel ilmiah, (g) artikel ilmiah popular, (h) modul, (i) karya terjemahan. (2) Siswa Menulis (Sulis) tujuanya adalah membudayakan siswa menghasilkan karya literasi, antara lain: (a) cerita pendek, (b) puisi, (c) novel, (d) komik, (e) cerita bergambar, (f) reportase, (g) poster, (h) digital visual literacy, (i) karya ilmiah remaja, (j) resensi/synopsis. (3) Kepala Madrasah Menulis (KAMIS) dan Pengawas Menulis (Panelis) tujuanya adalah meningkatkan kompetensi kepala madrasah dan pengawas madrasah dalam hal publikasi karya tulis, antara lain (a) menulis laporan hasil penelitian, (b) menulis buku popular, (c) artikel ilmiah, (d) artikel ilmiah popular, (e ) karya terjemahan (Sumarsilah et al. n.d.), (Widodo et al. 2015), (Hafiar 2015).

Untuk menyuksekan Gerakan Literasi Madrasah (GELEM) beberapa sekolah mengalami permasalahan antara lain rendahnya kompetensi guru madrasah dalam bidang penulisan karya tulis ilmiah khususnya menulis (a) proposal penelitian, (b) laporan hasil penelitian, dan (c) publikasi ilmiah. Untuk mengatasi permasalahan tersebut maka sangat perlu dilakukan pelatihan/workshop peningkatan kompetensi guru dalam bidang penulisan karya tulis ilmiah (Aisyah and Mahanani n.d.), (Eko Siswono dan Nur Djulaiqha 2017).

Tujuan pengabdian masyarakat ini adalah meningkatkan kompetensi guru dalam bidang penulisan karya tulis ilmiah sesuai dengan bidang keahlian yang mereka tekuni, tujuan secara khusus adalah menyiapkan sumber daya manusia para guru madrasah untuk lebih produktif dalam bidang literasi khususnya program Guru Menulis (GELIS), sehingga akan memberikan kontribusi besar untuk menyukseskan GERAMM di Kanwil Kemenag Provinsi jawa Timur.

\section{METODE PELAKSANAAN}

Untuk memudahkan pencapaian tujuan program, maka perlu disusun tahapan pelaksanaan kegiatan sebagai acuan pelaksanaan. Pertama adalah perencanaan, kedua adalah pelaksanaan dan ketiga adalah evaluasi dan pendampingan.

Berdasarkan Gambar 1, menjelaskan tahapan proses pelaksanaan peningkatan kompetensi guru bidang penulisan karya tulis ilmiah. Metode pelaksanaan dilakukan secara bertahap mulai perencanaan, pelaksanaan, evaluasi dan pendampingan. Peserta workshop adalah perwakilan guru dari beberapa Kabupaten/Kota di Jawa Timur dengan rekomendasi dari kepala kantor agama kabupaten/kota setempat dengan total 40 peserta.

Workshop dilaksanakan selama 3 hari atau setara dengan 32 Jam, model workshop dilakukan dengan model $30 \%$ teori (ceramah) dan $70 \%$ praktek (menulis proposal, laporan dan jurnal). Untuk memastikan peserta mampu menyerap materi maka metode yang digunakan adalah pre test dan post test. Dari hasil pre test tersebut panitia bisa mengetahui materi apa saja yang lemah dari peserta

Akfmad Sruji Bahtiar - Peningkatan Kompetensi guru madrasah bidang penulisan Karya tulis ilmiah melalui gerakan ayo membangun madrasah (GERAMMM) 
sehingga memudahkan pemateri lebih fokus untuk mengulas materi tersebut.
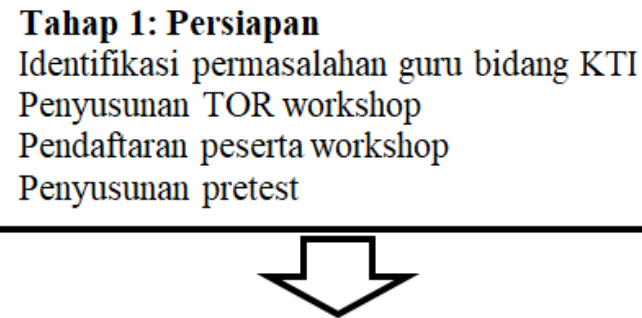

Tahap 2: Pelaksanaan

Pretest

Materi 1: Teknis penulisan proposal penelitian

Materi 2: Teknis menulis laporan PTK

Materi 3: Strategi menulis publikasi ilmiah

Materi 4: Teknis menulis publikasi di junal

Post test

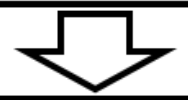

Tahap 3: Pendampingan

Rencana Tindak Lanjut

Membuat proposal dan laporan akhir penelitian

Menentukan tempat publikasi ilmiah

Komunikasi dan konsultasi

Publikasi

Gambar 1. Tahapan pelaksanaan

Hasil penilaian post test akan digunakan oleh panitia untuk mengetahui kemampuan peserta memahami materi workshop secara keseluruhan, hasil post test tersebut bisa dijadikan acuan untuk menentukan model pendampingan kepada peserta. Metode pendampingan dilakukan secara online dengan menggunakan aplikasi google document, sehingga pelaksana kegiatan mampu memonitoring progress kemajuan peserta.

Model pelaksanaan workshop direncanakan dengan metode ceramah, diskusi, praktek dan tanya jawab. Selama pelaksanaan workshop peserta sudah membawa bahan penelitian atau mereka minimum membawa judul yang akan didiskusikan pada saat acara workshop.

\section{HASIL DAN PEMBAHASAN}

Berdasarkan tahapan pelaksanaan program peningkatan kompetensi guru madrasah bidang KTI, tahap pertama adalah persiapan yaitu, (a) identifikasi permasalahan guru bidang KTI, bertujuan untuk merancang desain materi workshop sehingga tepat sasaran (b) penyusunan TOR workshop, bertujuan sebagai acuan menyusun kegiatan lengkap dengan durasi materi, capaian yang akan dicapai selama pelatihan, (c) penyusunan soal pre-test, bertujuan untuk mengetahui pemahaman setiap materi/session dalam pelatihan, kisi-kisi pembuatan soal pretest dapat dilihat pada Tabel 1 .

Tabel 1. Komposisi bobot pretest

\begin{tabular}{lc}
\hline Materi Pretest: & Bobot Soal \\
\hline 1. Kebijakan & $5 \%$ \\
2. Urgensi GERAMM & $10 \%$ \\
3. Penelitian Tindakan Kelas & $40 \%$ \\
4. Penulisan publikasi ilmiah & $35 \%$ \\
5. HKI & $10 \%$ \\
\hline
\end{tabular}

Tujuan pengabdian masyarakat ini adalah untuk meningkatkan kemampuan guru madrasah pada bidang KTI sehingga materi yang akan diberikan kepada para guru yaitu: kebijakan sekitar 5\%, urgensi kepentingan dan tujuan Gerakan Ayo Membangun Madrasah (GERAMM) sekitar 10\%, materi teknis pembuatan proposal PTK, penggunaan metode PTK, pembuatan laporan PTK sekitar $40 \%$, materi penulisan ilmiah sekitar 35\% dan hak kekayaan intelektual sekitar $10 \%$.

Tahap kedua adalah pelaksanaan yaitu: (a) pelaksanaan pre-test, (b) pelaksanaan workshop (kebijakan, urgensi GERAMM, penelitian tindakan kelas, penulisan publikasi ilmiah dan HKI), (c) pelaksanaan post-test. Hasil pre-test seluruh peserta dapat dilihat pada Gambar 2. 

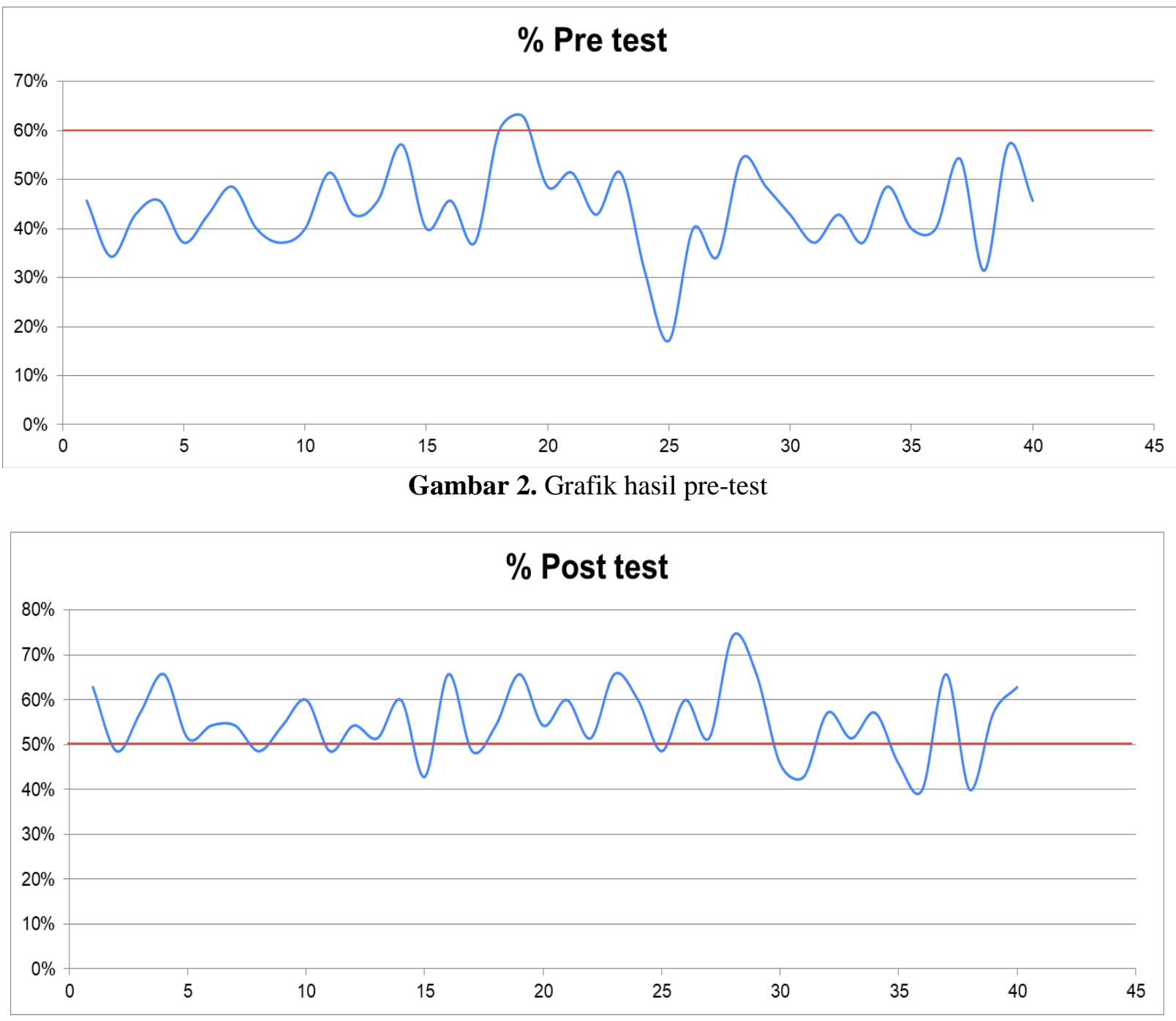

Gambar 3. Grafik hasil post-test

Metode pelaksanaan workshop peningkatan kompetensi guru Madrasah dalam bidang penulisan karya tulis ilmiah dilakukan dengan metode ceramah, diskusi dan praktek. Setiap pemateri selalu menyampaikan tujuan, target dari materi yang disampaikan kepada peserta, pada akhir session pemateri diminta untuk mereview atau mengulang materi yang sudah disampaikan, selanjutnya pemateri yang dipandu oleh moderator akan melakukan umpan balik materi yaitu membuka session Tanya jawab.

Khusus materi pemahaman penulisan proposal penelitian tindakan kelas, pemateri telah menyiapkan materi praktek yaitu menyusun beberapa pertanyaan yang sengaja disusun untuk mengajak para peserta belajar dari pertanyaan tersebut. Materi praktek diberikan dengan menyebarkan template pengisian PTS kepada peserta, content template PTK yang diberikan kepada peserta dapat dilihat pada Gambar 4.

Setelah peserta diberikan pemahaman tentang pentingnya PTK, maka selanjutnya peserta diberikan materi tentang tata tulis ilmiah khususnya pada Jurnal Ilmiah Nasional terakreditasi dengan tujuan Pemerintah melalui Kementrian Keagamaan Republik Indonesia Jawa Timur banyak para guru harus bisa lebih produktif, inovatif dan kreatif. Materi teknis penulisan jurnal ilmiah diberi materi penggunaan software mendeley, open grammarly dan plagiarism checker. Output

Akhmad Sruji Bahtiar - Peningkatan kompetensi guru madrasah 6idang penulisan karya tulis ilmiah melalui gerakan ayo membangun madrasah (GERAMM) 
yang diharapkan adalah lulusan yang memahami bisnis proses.

\begin{tabular}{|c|c|c|}
\hline \multirow[t]{3}{*}{ I } & 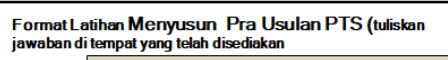 & 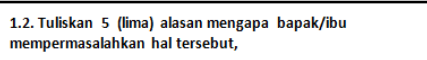 \\
\hline & & \\
\hline & Golongan /TMT & \\
\hline \multirow[t]{2}{*}{ Format Latihan } & 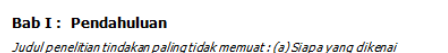 & \\
\hline & 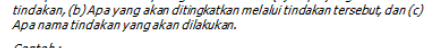 & \\
\hline \multirow{7}{*}{$\begin{array}{l}\text { Menyusun Pra Usulan } \\
\text { Penelitan Tindakan } \\
\text { Sekolah (PTS) }\end{array}$} & 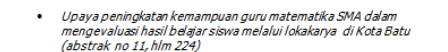 & \\
\hline & - · & \\
\hline & 1.1. Isikan rancenganj judul Prs Anda & 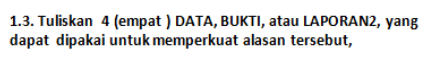 \\
\hline & Siapa yang atan diena at tindatan & \\
\hline & Apa yang alan ditingalataran melalui indidalan tersebut & \\
\hline & & \\
\hline & Apan nama tindatan yang gatan dilackularn. & \\
\hline
\end{tabular}

Gambar 5. Template isian proposal PTS

Dari 35 soal pretest peserta rata-rata hanya mampu menjawab 16 soal dengan benar, artinya rata-rata sekitar 19 soal tidak bisa dijawab atau sekitar $44 \%$, hal tersebut dipengaruhi karena peserta belum mengetahui tentang materi tersebut.

Setelah dilakukan pemberian materi kepada peserta, dari 35 soal post-test peserta rata-rata mampu menjawab $75 \%$ dari seluruh soal yang diberikan, artinya ada peningkatan kompetensi guru bidang KTI sebesar $31 \%$, hal tersebut dipengaruhi oleh pemahaman peserta terhadap materi yang disampaikan oleh pemateri.

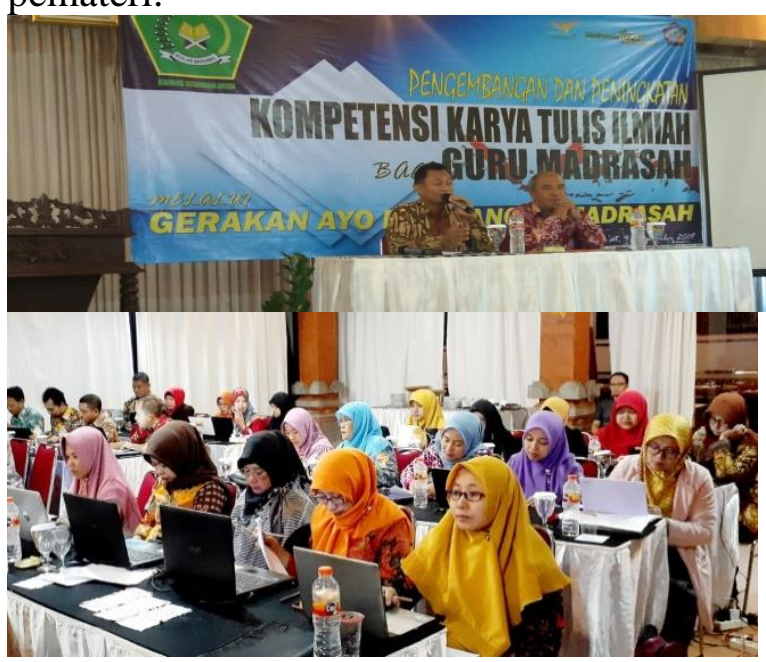

Gambar 6. Pelaksanaan workshop
Hasil capaian pelaksanaan post-test setelah workshop memiliki dampak yang positif terhadap peningkatan capaian kompetensi guru seperti terlihat pada Gambar 4. Rata-rata peningkatan pencapai kompetensi guru mencapai $\pm 31 \%$ dari hasil pre-test. Sebagai wujud tindak lanjut workshop penulisan proposal tindakan kelas sampai bisa menulis dijurnal akan dilakukan upgrading atau updating karya yang sudah dibuat menjadi tulisan karya ilmiah.

\section{KESIMPULAN}

Kesimpulan yang diperoleh pada program workshop peningkatan kompetensi guru bidang KTI adalah para peserta telah mampu meningkatkan pemahamannya tentang penulisan KTI sebesar $\pm 31 \%$. Metode yang digunakan pada saat workshop adalah action research, metode ini sangat cocok untuk digunakan dalam pelaksanaan pembelajaran, workshop dan kegiatan lain yang memerlukan sebuah analisa pada setiap kegiatanya. Kontribusi workshop ini akan menghasilkan luaran publikasi dari masingmasing peserta karena termasuk kewajiban mereka untuk memperoleh sertifikat workshop. Untuk memastikan keberlanjutan program ini perlu dilakukan pendampingan secara langsung maupun secara daring.

Akfmad Sruji Bahtiar - Peningkatan Kompetensi guru madrasah bidang penulisan Karya tulis ilmiah melalui gerakan ayo membangun madrasah (GERAMM) 


\section{UCAPAN TERIMA KASIH}

Ucapaan terima kasih kepada Kementrian Agama Republik Indoesia Propinsi Jawa Timur yang telah mendukung terlaksananya workshop GERAMM.

\section{DAFTAR PUSTAKA}

Aisyah, Eny Nur, and Putri Mahanani. "Pelatihan Menulisan Artikel Ilmiah Bagi Guru Sekolah Dasar Dan Taman Kanak-Kanak Kecamatan Tajinan Kabupaten Malang." : 22-26.

Ardinata, Lukhy. 2016. Upaya Peningkatan Kemampuan Guru Dalam Menulis Karya Ilmiah.

Dr. Achmad Syuruji, M.PdI. 2019. Buku Panduan Khusus GERAMM.

Eko Siswono dan Nur Djulaiqha. 2017. "Peningkatan Kompetensi Profesional Guru Ips." edukasi IPS 01(1): 12-20.

Florentina Maria Titin Supriyanti. 2009. Workshop Peningkatan Profesionalisme Guru Melalui Penelitian Tindakan Kelas.

Hafiar, Hanny. 2015. "Peningkatan Pendidikan Dan Pengembangan Kompetensi Guru SMA Negeri 1 Katapang Melalui Partisipasi Dalam Publikasi Akademis Di Media Massa." Dharmakarya 4(2): 88-92. http://jurnal.unpad.ac.id/dharmakarya/ar ticle/view/10032.

https://jatim.kemenag.go.id/. 2019. "Kabid Pendma Membangun Madrasah Melalui Geramm." Kemenag Jatim.

Sedayu, Negeri, and Tanggal Juli. 2011. Pengembangan Profesionalisme Guru Melalui Penulisan Karya Tulis Ilmiah.

Septiani, Pipit Eka. 2019. "Pelatihan Dan Pendampingan Penggunaan Media Pembelajaran Matematika Pada Orang Tua Siswa Sekolah Dasar (SD)." Dinamisia : Jurnal Pengabdian Kepada Masyarakat 3(1): 105-11.

Sumarsilah, Siti et al. "Pelatihan Dan Pendampingan Penulisan Artikel Imiah Hasil Penelitian Bermuatan Pendidikan Karakter Bagi Guru MI Se Kota
Malang." : 38-45.

Widodo, Suwarno, . Suyoto, . Supardi, and Agus Wismanto. 2015. "Peningkatan Kompetensi Guru Profesional Berbasis Penulisan Artikel Hasil Ptk Bagi Guru Anggota Pgri Di Kabupaten Purworejo." E-Dimas 5(1): 78 .

Akhmad Sruji Bahtiar - Peningkatan kompetensi guru madrasah 6idang penulisan karya tulis ilmiah melalui gerakan ayo membangun madrasah (GERAMM) 